Gut, 1961, 2, 123

\title{
The measurement of gastrointestinal protein loss by a new method
}

\author{
K. N. JEEJEEBHOY AND N. F. COGHILL \\ From West Middlesex Hospital, Isleworth
}

SYNOPSIS This paper reports a new method of estimating protein loss from the alimentary tract using radio-iodinated human serum albumin (RIHSA). This has advantages over the use of ${ }^{131}$ I-PVP.

The term 'exudative enteropathy' (Gordon, 1959) has been applied to conditions in which protein may be lost from the body by passing through the intestinal wall. Several methods have been employed to study this phenomenon. Paper electrophoresis and immunophoresis have been used to determine the presence of autogenous human albumins and globulins in intestinal juices (Schwartz and Jarnum, 1959; Gross, Embree, Bally, Shipp, and Thorn, 1960). Such methods are mainly qualitative. Gordon (1959) used radio-iodinated polyvinyl pyrrolidone, and Schwartz and Thomsen (1957) used radio-iodinated human serum albumin (RIHSA) in attempts to study intestinal protein loss quantitatively. Polyvinyl pyrrolidone (PVP) is a synthetic polymer of molecular weight averaging about 40,000 . It has been used as a plasma substitute but unlike albumin it is unaffected by digestive juices. It is thought that it cannot be absorbed from the alimentary tract. These properties make it possible to recover in the faeces PVP excreted into the gut.

In a study of patients with idiopathic hypoproteinaemia Gordon (1959) showed that after an intravenous injection of ${ }^{131}$ I-PVP the faeces contained an abnormally large amount of it. Similar results were obtained by Schwartz and Jarnum (1959) in a case of hypertrophic gastritis. These results indicated that hypoproteinaemia in these cases was associated with an increased excretion of a macromolecular substance similar physically to plasma albumin (molecular weight 66,000), and suggested increased excretion of protein into the gastrointestinal tract.

There are difficulties in the use of PVP. It is possible that it may sometimes be partially reabsorbed. It is selectively trapped by the reticuloendothelial system. It does not have a uniform molecular size, and it may be that different sized molecules are excreted at different rates in the gut, as in the kidney. There are facets of protein excretion which the use of PVP cannot illuminate. For example, the magnitude of PVP excretion does not necessarily equal that of protein excretion as the two are not chemically comparable. Furthermore, PVP excretion may not be increased in states of increased protein loss due to excessive mucosal desquamation, or to alteration in the quantity, or protein content, of intestinal secretions.

This paper describes a new method of studying protein loss in the gut using RIHSA, which does not have the disadvantages of ${ }^{131}$ I-PVP. With this technique patients with hypoproteinaemia and oedema have been found with increased RIHSA excretion but normal ${ }^{131}$ I-PVP excretion.

\section{MATERIALS AND METHODS}

Details of the 17 patients studied are given in Table III where they are shown divided into four groups.

PROTEIN TURNOVER This was studied by the use of RIHSA. The material was obtained from the Radiochemical Centre at Amersham. It was manufactured by a modification of the jet method of McFarlane (1956). The specific activity of the material was about $63 \mu \mathrm{c}$. per $\mathrm{mg}$. The degree of iodination was one atom of iodine to each two molecules of albumin. The material was diluted and mixed with albumin to give a final concentration of $2 \mathrm{mg}$. of albumin per ml. containing $2 \mu \mathrm{c}$. of activity. The method of studying protein turnover was that of Berson, Yalow, Schreiber, and Post (1953).

1 The patient is given Lugol's iodine 10 minims b.d. for two days before the test and for its duration.

2 From 20 to $30 \mu \mathrm{c}$. of RIHSA is injected intravenously.

3 Blood is taken in a heparinized syringe 10 minutes after the injection to obtain the initial activity after plasma distribution has occurred.

The plasma radioactivity is determined daily until its decline reaches a constant rate, which may take up to one week.

4 Simultaneously 24-hour urinary and faecal radioactivities are determined and the percentage of retained radioactivity is calculated by subtracting the cumulative excreted value from $100 \%$ (Fig. 1). 

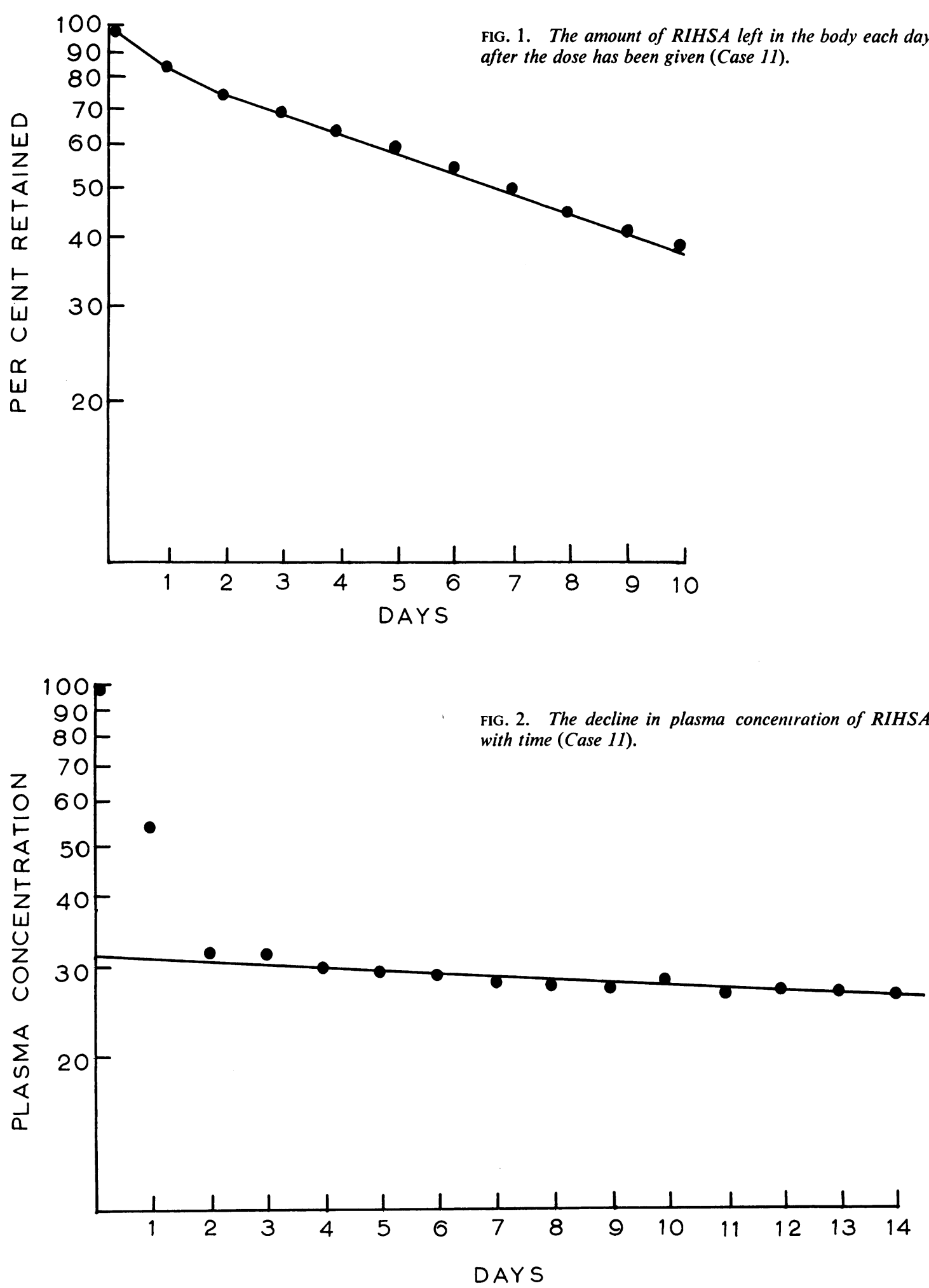


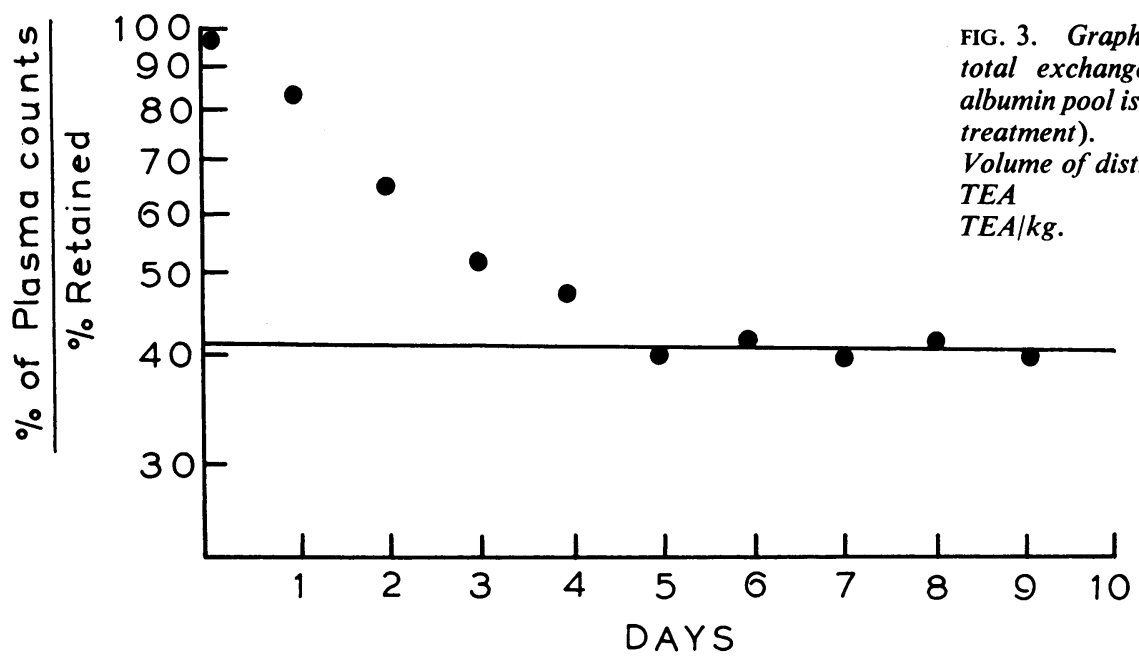

5 The activity falls off rapidly at first (Fig. 2) due to dilution in the extravascular pool and destruction of labile molecules.

6 After the initial rapid decay the ratio of the plasma activity on any day (expressed as a percentage of the initial plasma activity) to the percentage retained on that day becomes a constant figure at the point when the decline in the plasma is equal in its rate to the urinary excretion (Fig. 3). At this stage the factor of extravascular dilution is constant. The product of this final dilution and the total plasma concentration of albumin gives the total exchangeable albumin (TEA), or albumin pool.

To determine the turnover of the RIHSA per day, the urinary excretion has to be corrected for the decay in the plasma by plotting the ratio of the urinary excretion in any given day against the percentage retained in the body on that day. This ratio becomes a constant factor and indicates the percentage albumin turnover per day (Fig. 4).

BIOLOGICAL HALF-LIFE This is calculated by extrapolating the slope of plasma radioactivity after it shows a constant rate of fall, to zero time (Fig. 2). The number of days required to reduce the activity to half the value at the intersection is the biological half-life $\left(T_{\frac{1}{2}}\right)$.

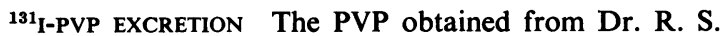
Gordon was dialysed to remove free iodide before use. The subjects were given $10 \mu \mathrm{c}$. of ${ }^{131}$ I-PVP intravenously and the amount excreted in the faeces was estimated for six days.

METHOD FOR STUDYING PROTEIN EXCRETION IN GASTROINTESTINAL TRACT QUANTITATIVELY USING RIHSA We first demonstrated the excretion of RIHSA in the gastrointestinal tract by intubating three patients who had received $30 \mu \mathrm{c}$. of RIHSA intravenously and collecting the jejunal secretions from $22 \mathrm{~cm}$. beyond the duodenojejunal flexure. Patients investigated were (1) a patient with quiescent ulcerative colitis (Case 7); (2) a patient with Crohn's disease in a phase of remission (Case 9); (3) a person under investigation with complaints of abdominal distension but with no demonstrable abnor-

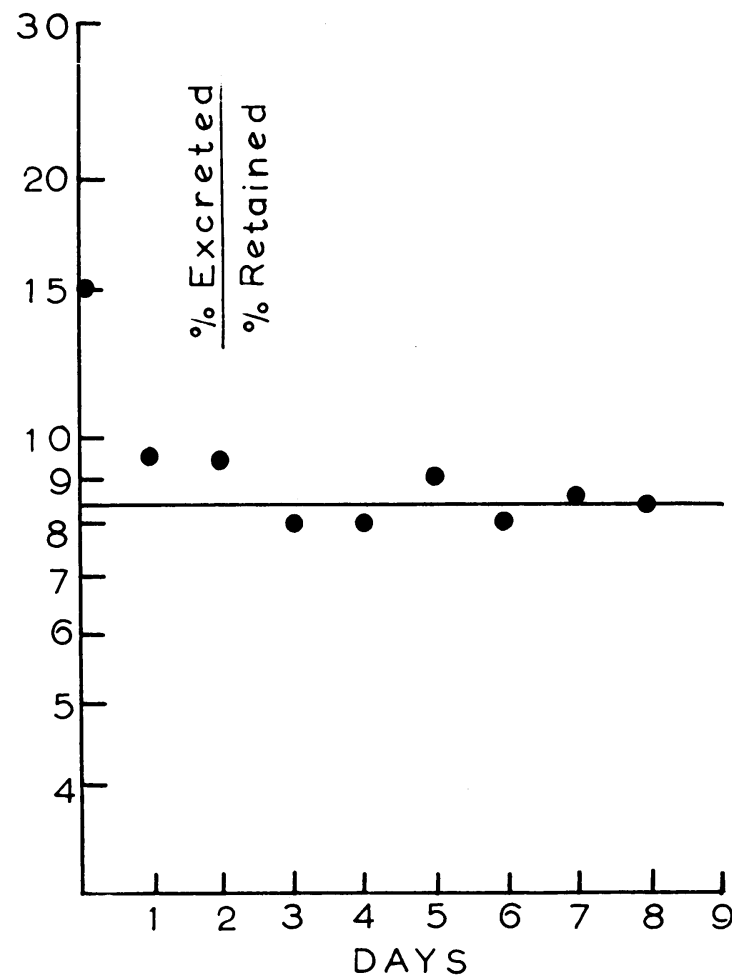

FIG. 4. The percentage of albumin turned over in one day (Case 15 before treatment).

Average daily turnover $=8.4 \%$.

Albumin turned over per day $=15.0 \mathrm{~g}$. 
mality of the gastrointestinal tract (Case D.H.). Cases 7 and D.H. were thought to have normal small intestinal function. Case 9 had a normal RIHSA turnover during this study. Jejunal juice was collected in vessels containing $10 \%$ trichloracetic acid solution (TCA) and in empty ones. The latter were incubated for 20 minutes at $37^{\circ} \mathrm{C}$. to allow intestinal enzymes to act on the RIHSA. The precipitate was separated and the supernatant fluid treated with potassium iodide and potassium iodate to liberate iodine which was extracted with chloroform.

The results (Table I) showed that initially only 4 to $5 \%$

\section{TABLE I}

PARTITION OF RADIOACTIVITY IN JEJUNAL JUICE

\begin{tabular}{|c|c|c|c|}
\hline \multirow[t]{2}{*}{ Case No. } & \multirow{2}{*}{$\begin{array}{l}\text { TCA } \\
\text { Precipitate } \\
(\%)\end{array}$} & \multicolumn{2}{|l|}{ Supernatant } \\
\hline & & $\begin{array}{l}\text { Non-Ionic } \\
\text { Iodine (\%) }\end{array}$ & $\begin{array}{l}\text { Free Iodide } \\
(\%)\end{array}$ \\
\hline \multicolumn{4}{|c|}{ Jejunal juice \pm trichloracetic acid $(T C A)$} \\
\hline $\begin{array}{l}7 \\
9 \\
\text { D.H. }\end{array}$ & $\begin{array}{l}56 \cdot 5 \\
60 \cdot 1 \\
58 \cdot 4\end{array}$ & $\begin{array}{l}38 \cdot 6 \\
34 \cdot 8 \\
35 \cdot 0\end{array}$ & $\begin{array}{l}4.9 \\
5 \cdot 1 \\
4 \cdot 6\end{array}$ \\
\hline \multicolumn{4}{|c|}{ Jejunal juice incubated at $37^{\circ}$ for 20 minutes } \\
\hline $\begin{array}{l}7 \\
9 \\
\text { D.H. }\end{array}$ & $\begin{array}{l}\text { Nil } \\
\text { Nil } \\
\text { Nil }\end{array}$ & $\begin{array}{l}76 \cdot 1 \\
82 \cdot 6 \\
80 \cdot 5\end{array}$ & $\begin{array}{l}23 \cdot 9 \\
17 \cdot 4 \\
19 \cdot 5\end{array}$ \\
\hline
\end{tabular}

of the activity was in the form of free iodides, the rest being bound to protein or in a non-ionic form. The digested products contained more free iodide and no protein. Similar results were obtained by Holman, Nickel, and Sleisenger (1959) who showed by electrophoresis that the protein-bound radioactivity resided in the albumin. intestinal tract and was subsequently digested we then studied the efficiency of Amberlite resin IRA-400 (Cl) (analytical grade) as an agent for absorbing these products of digestion. The resin, in the ratio one to nine by weight, was added to an aliquot of jejunal juice after incubation as previously described. It took up about $80 \%$ of the radioactivity (Cases 7, 9, and D.H., Table II).

To study the recovery of RIHSA in vivo using Amberlite, $10 \mu \mathrm{c}$. of RIHSA was given orally with the Amberlite. The dose of Amberlite was increased in successive experiments and $5 \mathrm{~g}$. four hourly was found to be optimal and resulted in about $80 \%$ recovery of the radioactivity in the faeces (Cases $A, B$, and $C$, Table II).

In order to determine the excretion of RIHSA in the
Having shown that RIHSA was excreted in the gastro-

gut in our subjects we gave them $5 \mathrm{~g}$. of the Amberlite resin four hourly by mouth. The 24 -hour faecal radioactivity was determined daily.

The amount of radioactivity excreted in the faeces on a given day depends on the concentration of RIHSA in the plasma on that day. Hence the figure for faecal radioactivity on any particular day must be corrected according to the activity present in the plasma on that day, expressed as a percentage of the activity present on the day the dose of RIHSA was given (the "percentage radioactivity'). Now faecal activity on one day does not necessarily correspond to the radioactivity excreted into the gut on the previous day because of variations in intestinal motility. We therefore made the correction in the following manner. The total radioactivity was measured in the faeces collected over a four-day period and the mean daily activity was multiplied by the mean 'percentage radioactivity' in the plasma for the same period.

\section{RESULTS}

ALBUMIN TURNOVER The biological half-life $\left(\mathrm{T}_{1}\right)$ of RIHSA in normal subjects was found by Berson et al. (1953) to be always above 12.5 days with an average range of 17 to 20 days. The daily turnover was found to be less than $5.5 \%$ per day.

The patients we studied could be placed in four groups and are thus shown in Table III. The $\mathbf{T}_{\mathbf{1}}$ and the daily breakdown in the three control subjects (Cases 1, 2, and 3) in Group I and in the four patients (Cases 4, 5, 6, and 7) with inactive gastrointestinal disorders in Group II, were within normal limits.

Four patients in Group III (Cases 9, 14, 15, and 16) had a markedly accelerated albumin turnover with a $T_{1}$ respectively of $3 \cdot 8,5 \cdot 1,5 \cdot 5$, and 3.5 days. Hypoproteinaemia and oedema were absent in these at the time of study. Four other patients who had hypoproteinaemia and oedema at the time of study (Cases $9,10,15$, and 17) with a similarly short $T_{1}$ were placed separately in Group IV.

The findings in two patients with chronic small bowel obstruction offered an interesting contrast. The $T_{t}$ in Case 8 , suffering from relatively inactive Crohn's disease, was shortened to $\mathbf{7 . 2}$ days, but in Case 11, suffering from non-inflammatory obstruction due to endometriosis, it was normal (22 days). The shortened $T_{1}$ in Case 8 could be explained only partly by increased intestinal loss because the

TABLE II

RECOVERY OF RIHSA WITH AMBERLITE

\begin{tabular}{|c|c|c|c|c|c|c|}
\hline Case No. & $\begin{array}{l}\text { Jejunal Juice/Amberlite Ratio } 9 / 1 \\
\text { (\% Recovery) }\end{array}$ & Case No. & Dose & \multicolumn{3}{|c|}{$\%$ Recovery in Faeces } \\
\hline $\begin{array}{l}\text { In vitro } \\
7 \\
9 \\
\text { D.H }\end{array}$ & $\begin{array}{l}85 \\
79 \\
89\end{array}$ & $\begin{array}{c}\text { In vivo } \\
\mathbf{A} \\
\mathbf{B} \\
\mathbf{C}\end{array}$ & $\begin{array}{l}5 \mathrm{~g} . \text { six hourly } \\
5 \mathrm{~g} \text {. four hourly } \\
5 \mathrm{~g} \text {. two hourly }\end{array}$ & $\begin{array}{l}55 \\
79 \\
80\end{array}$ & $\begin{array}{l}63 \\
74 \\
76\end{array}$ & $\begin{array}{l}65 \\
84 \\
82\end{array}$ \\
\hline
\end{tabular}


TABLE III

PLASMA ALBUmin LEVELS AND BIOLOGICAL HALF-LIFE ( $\left.\mathrm{T}_{\frac{1}{2}}\right)$ AND DAILY TURNOVER OF RIHSA IN PATIENTS STUDIED

\begin{tabular}{|c|c|c|c|c|c|c|}
\hline $\begin{array}{l}\text { Case } \\
\text { No. }\end{array}$ & Clinical State & Sex & Age & $\begin{array}{l}\text { Plasma Albumin } \\
(\mathrm{g} .1100 \mathrm{ml} .)\end{array}$ & $\begin{array}{l}T_{\frac{1}{2}} \\
\text { (days) }\end{array}$ & $\begin{array}{l}\text { Daily Turnover } \\
\text { (\%) }\end{array}$ \\
\hline \multicolumn{7}{|c|}{ Group I: Control subjects } \\
\hline $\begin{array}{l}\mathbf{1} \\
\mathbf{2} \\
\mathbf{3}\end{array}$ & $\begin{array}{l}\text { Convalescent myocardial infarction without bowel } \\
\text { disturbance }\end{array}$ & $\begin{array}{l}\mathbf{M} \\
\mathbf{M} \\
\mathbf{M}\end{array}$ & $\begin{array}{l}65 \\
55 \\
47\end{array}$ & $\begin{array}{l}4 \cdot 1 \\
3 \cdot 9 \\
4 \cdot 0\end{array}$ & $\begin{array}{l}17 \cdot 0 \\
22 \cdot 0 \\
20 \cdot 0\end{array}$ & $\begin{array}{l}4 \cdot 1 \\
3 \cdot 1 \\
3 \cdot 2\end{array}$ \\
\hline \multicolumn{7}{|c|}{ Group II: Patients with inactive gastrointestinal disorders } \\
\hline 4 & Partial gastrectomy & $\mathbf{F}$ & 49 & $3 \cdot 1$ & $17 \cdot 0$ & $4 \cdot 1$ \\
\hline 5 & & $\mathbf{F}$ & 36 & 3.8 & $12 \cdot 0$ & 5.7 \\
\hline 6 & Asymptomatic quiescent ulcerative colitis & $\mathbf{F}$ & 29 & $3 \cdot 8$ & $28 \cdot 0$ & $2 \cdot 4$ \\
\hline 7 & & $\mathbf{M}$ & 62 & $3 \cdot 7$ & $14 \cdot 0$ & $5 \cdot 0$ \\
\hline \multirow{2}{*}{\multicolumn{7}{|c|}{$\begin{array}{l}\text { Group III: Patients with gastrointestinal disease but without hypoproteinaemia or oedema } \\
8\end{array}$}} \\
\hline 8 & & & & & & \\
\hline 9 & Crohn's disease, in remission & $\mathbf{F}$ & 46 & 3.6 & $\begin{array}{l}7 \cdot 0 \\
3.8\end{array}$ & $9 \cdot 6$ \\
\hline 11 & Chronic small intestinal obstruction due to endometriosis & $\mathbf{F}$ & 48 & 3.9 & $\begin{array}{r}3.8 \\
22.0\end{array}$ & $\begin{array}{r}18 \cdot 2 \\
3 \cdot 1\end{array}$ \\
\hline 12 & Steatorrhoea after partial gastrectomy & $\mathbf{M}$ & 66 & $3 \cdot 1$ & 6.0 & 11.5 \\
\hline 13 & Diarrhoea with pleural effusion (undiagnosed) & $\mathbf{F}$ & 64 & $3 \cdot 1$ & $13 \cdot 0$ & $5 \cdot 4$ \\
\hline 14 & Gluten enteropathy (pre-treatment) & $\mathbf{M}$ & 16 & $3 \cdot 6$ & $5 \cdot 1$ & $13 \cdot 0$ \\
\hline 15 & Idiopathic steatorrhoea, after partial recovery & $\mathbf{F}$ & 26 & 3.9 & $5 \cdot 5$ & $13 \cdot 6$ \\
\hline 16 & Crohn's disease, in relapse & $\mathbf{F}$ & 39 & $4 \cdot 0$ & $3 \cdot 5$ & 20.5 \\
\hline \multicolumn{7}{|c|}{ Group IV: Patients with gastrointestinal disease and with hypoproteinaemia and oedema } \\
\hline 9 & Crohn's disease, when active & $\mathbf{F}$ & 46 & $2 \cdot 7$ & $3 \cdot 5$ & $20 \cdot 6$ \\
\hline 10 & Crohn's disease, before resection & $\mathbf{F}$ & 37 & $2 \cdot 5$ & $2 \cdot 8$ & 24.5 \\
\hline 15 & Idiopathic steatorrhoea, before treatment & $\mathbf{F}$ & 26 & $2 \cdot 9$ & $5 \cdot 1$ & $13 \cdot 6$ \\
\hline 17 & Tuberculous strictures (healed) of small intestine & $\mathbf{F}$ & 37 & $2 \cdot 8$ & $3 \cdot 2$ & 21.0 \\
\hline
\end{tabular}

faecal excretion of RIHSA was only a little above normal $(3.4 \%)$. The turnover of RIHSA in these patients was respectively $9.6 \%$ and $3.1 \%$.

EXCRETION OF ${ }^{131}$ I-PVP The PVP excretion in three control subjects (Table IV) was below $1.5 \%$ of the dose, the upper limit of normal suggested by Gordon (1959).

In four patients with, and in three without, oedema the results were all within the normal range (Table IV). In these patients the PVP method did not indicate any gastrointestinal protein loss although the RIHSA $T_{\frac{1}{z}}$ in all was greatly shortened. However, in three of the four patients with oedema a little more PVP was lost than from those without oedema, although the loss was still within the normal range.

STUDY OF FAECAL RADIOACTIVITY USING RIHSA AND AMBERLITE IRA-400 The results of the excretion of RIHSA with Amberlite suggested that our patients could be regrouped as follows:
1 Control subjects excreted 1.7 to $1.9 \%$ of the radioiodine daily (Table V) corresponding to about $5 \mathrm{~g}$. of albumin per day (calculated from the total exchangeable albumin). The daily turnover of

\section{TABLE V}

ALBUMIN TURNOVER AND FAECAL EXCRETION OF RIHSA IN NORMAL SUBJECTS (GROUP I OF TABLE III)

\begin{tabular}{|c|c|c|c|c|}
\hline $\begin{array}{l}\text { Case } \\
\text { No. }\end{array}$ & Clinical State & $\begin{array}{l}T_{\frac{1}{2}} \\
\text { (days) }\end{array}$ & $\begin{array}{l}\text { Daily } \\
\text { Turnover } \\
(\%)\end{array}$ & $\begin{array}{l}\text { Daily Excretion } \\
\text { with Amberlite } \\
\text { (\% of dose) }\end{array}$ \\
\hline $\begin{array}{l}1 \\
2 \\
3\end{array}$ & $\begin{array}{l}\text { Convalescent myo- } \\
\text { cardial infarction }\end{array}$ & $\begin{array}{l}17.0 \\
22.0 \\
20.0\end{array}$ & $\begin{array}{l}4 \cdot 1 \\
3 \cdot 1 \\
3 \cdot 2\end{array}$ & $\begin{array}{l}1.7 \\
1.8 \\
1.9\end{array}$ \\
\hline
\end{tabular}

RIHSA amounted to $3 \cdot 1$ to $4 \cdot 1 \%$ of RIHSA per day corresponding to a turnover of 9.4 to $12.3 \mathrm{~g}$. of albumin per day. Similar results were seen in the patients whose gastrointestinal tracts were functionally normal at the time of study (Table VI).

TABLE IV

${ }^{131}$ I-PVP EXCRETION OVER SIX DAYS AFTER AN INTRAVENOUS DOSE

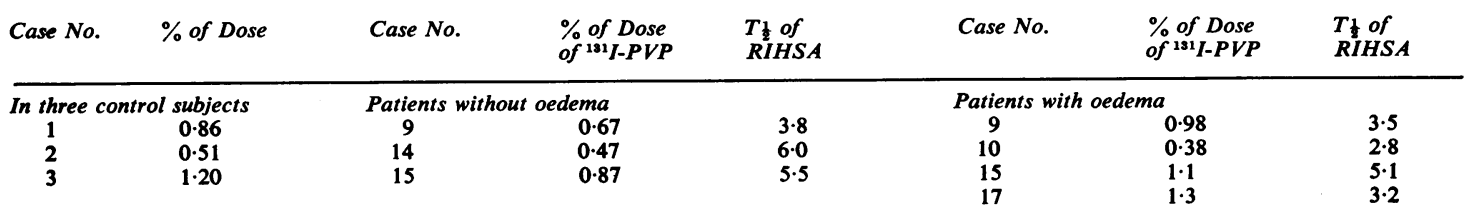


TABLE VI

ALBUMIN TURNOVER AND FAECAL EXCRETION OF RIHSA IN PATIENTS WITH INACTIVE GASTROINTESTINAL DISEASE (GROUP II OF TABLE III)

\begin{tabular}{|c|c|c|c|c|}
\hline $\begin{array}{l}\text { Case } \\
\text { No. }\end{array}$ & Clinical State & $\begin{array}{l}T_{\frac{1}{2}} \\
\text { (days) }\end{array}$ & $\begin{array}{l}\text { Daily } \\
\text { Turnover } \\
(\%)\end{array}$ & $\begin{array}{l}\text { Daily Excretion } \\
\text { with Amberlite } \\
\text { (\% of dose })\end{array}$ \\
\hline $\begin{array}{l}4 \\
5 \\
6 \\
7\end{array}$ & $\begin{array}{l}\text { Partial gastrectomy } \\
\text { Symptomless, quies- } \\
\text { cent ulcerative colitis }\end{array}$ & $\begin{array}{l}17 \cdot 0 \\
12 \cdot 0 \\
28 \cdot 0 \\
14 \cdot 0\end{array}$ & $\begin{array}{l}4 \cdot 1 \\
5 \cdot 7 \\
2 \cdot 4 \\
5 \cdot 0\end{array}$ & $\begin{array}{l}1.9 \\
1.8 \\
1.9 \\
1.6\end{array}$ \\
\hline
\end{tabular}

2 The second group was composed of the four patients with non-specific intestinal disorders (Table VII). The excretion of radioiodine into the gastrointestinal tract in these patients amounted to $2 \cdot 1$ to $4.8 \%$ daily, corresponding to a loss of about $7 \mathrm{~g}$. albumin per day.

3 The third group was composed of patients with hypoalbuminaemia and oedema (Table VIII). The excretion of RIHSA was 12.9 to $18.9 \%$ daily corresponding to a loss of about $22 \mathrm{~g}$. of albumin per day.

4 The fourth group (Table IX) comprised patients in whom hypoproteinaemia and oedema were absent but in whom the endogenous protein breakdown of RIHSA was 7.7 to $20.5 \%$ daily which markedly exceeded the amount excreted in the gastrointestinal tract. Gastrointestinal excretion in this group (2.4 to $2.5 \%)$ was the same as in the patients in Group 2.
The effect of a gluten-free diet in a patient with gluten enteropathy (Case 14) and of antibiotics for three weeks in a patient with idiopathic steatorrhoea (Case 15) is shown in Table $X$.

\section{DISCUSSION}

The method described for the study of the excretion of protein into the gastrointestinal tract has the advantages of using radioiodinated albumin as a tracer. Radio-iodinated human serum albumin and native albumin are closely related to each other chemically and physically.

That this method actually measures the albumin excreted and not dissociated radioiodine is indicated by the following evidence:

Most of the radioactivity excreted was at first either protein-bound or in a non-ionic form (found to be mono-iodo-tyrosine by Parkins, Dimitriadou, and Booth, 1960). The free iodide constituted only $4.5 \%$ of the radioactivity.

This radioactivity was taken up by Amberlite to the extent of $80 \%$. Hence the faecal radioactivity after the administration of this resin was quantitatively representative of the excreted albumin.

The study of a group of subjects with rapid turnover of RIHSA in the plasma without increased activity in the faeces indicates that the excreted radioactivity is not secondary to the shortened

\section{TABLE VII}

ALBUMIN TURNOVER AND FAECAL EXCRETION OF RIHSA IN PATIENTS WITH NON-SPECIFIC GASTROINTESTINAL DISORDERS (PART OF GROUP III OF TABLE III)

\begin{tabular}{|c|c|c|c|c|c|}
\hline \multirow[t]{2}{*}{ Case No. } & \multirow[t]{2}{*}{ Condition } & \multirow[t]{2}{*}{$\begin{array}{l}T_{\frac{1}{2}} \\
(\text { days })\end{array}$} & \multirow{2}{*}{$\begin{array}{l}\text { Daily } \\
\text { Albumin } \\
\text { Turnover } \\
(\%)\end{array}$} & \multicolumn{2}{|c|}{$\begin{array}{l}\text { Daily Excretion in Gastrointestina } \\
\text { Tract }\end{array}$} \\
\hline & & & & RIHSA (\%) & Albumin $^{1}(g)$. \\
\hline $\begin{array}{r}8 \\
11 \\
12 \\
13\end{array}$ & $\left.\begin{array}{l}\text { Crohn's disease } \\
\begin{array}{l}\text { Endometriosis } \\
\text { Partial gastrectomy steatorrhoea } \\
\text { Diarrhoea }\end{array}\end{array}\right\}$ small intestinal obstruction & $\begin{array}{r}7 \cdot 2 \\
22 \cdot 0 \\
6 \cdot 0 \\
13 \cdot 0\end{array}$ & $\begin{array}{r}9 \cdot 6 \\
3 \cdot 1 \\
11 \cdot 5 \\
5 \cdot 4\end{array}$ & $\begin{array}{l}3 \cdot 4 \\
2 \cdot 2 \\
4 \cdot 8 \\
2 \cdot 1\end{array}$ & $\begin{array}{l}5 \cdot 7 \\
7 \cdot 6 \\
8 \cdot 4 \\
5 \cdot 4\end{array}$ \\
\hline
\end{tabular}

${ }^{1}$ Calculated from the total exchangeable albumin (TEA).

TABLE VIII

ALBUMIN TURNOVER AND PAECAL EXCRETION OF RIHSA IN PATIENTS WITH HYPOPROTEINAEMIA AND OEDEMA (GROUP IV OF TABLE III)

\begin{tabular}{|c|c|c|c|c|c|}
\hline \multirow[t]{2}{*}{ Case No. } & \multirow[t]{2}{*}{ Condition } & \multirow[t]{2}{*}{$\begin{array}{l}T_{\frac{1}{2}} \\
(\text { days })\end{array}$} & \multirow{2}{*}{$\begin{array}{l}\text { Daily } \\
\text { Albumin } \\
\text { Turnover } \\
(\%)\end{array}$} & \multicolumn{2}{|c|}{$\begin{array}{l}\text { Daily Excretion in Gastrointestinal } \\
\text { Tract }\end{array}$} \\
\hline & & & & RIHSA (\%) & Albumin $^{1}$ (g.) \\
\hline $\begin{array}{r}9 \\
10 \\
15 \\
17\end{array}$ & $\begin{array}{l}\text { Crohn's disease (active) } \\
\text { Idiopathic steatorrhoea (active) } \\
\text { Tuberculous strictures of small intestine }\end{array}$ & $\begin{array}{l}3 \cdot 5 \\
2 \cdot 8 \\
5 \cdot 1 \\
3 \cdot 2\end{array}$ & $\begin{array}{l}20 \cdot 6 \\
24 \cdot 5 \\
13 \cdot 6 \\
21 \cdot 0\end{array}$ & $\begin{array}{l}18 \cdot 9 \\
15 \cdot 5 \\
17 \cdot 2 \\
12 \cdot 9\end{array}$ & $\begin{array}{l}17 \cdot 8 \\
15 \cdot 2 \\
30 \cdot 9 \\
22 \cdot 5\end{array}$ \\
\hline
\end{tabular}

'Calculated from the TEA. 
TABLE IX

ALBUMIN TURNOVER AND FAECAL EXCRETION OF RIHSA IN PATIENTS WITH SMALL BOWEL DISEASE WITHOUT HYPOPROTEINAEMIA OR OEDEMA (PART OF GROUP III OF TABLE III)

\begin{tabular}{|c|c|c|c|c|c|}
\hline \multirow[t]{2}{*}{ Case No. } & \multirow[t]{2}{*}{ Condition } & \multirow[t]{2}{*}{$\begin{array}{l}T_{1} \\
\text { (days) }\end{array}$} & \multirow{2}{*}{$\begin{array}{l}\text { Daily } \\
\text { Albumin } \\
\text { Turnover } \\
(\%)\end{array}$} & \multicolumn{2}{|c|}{$\begin{array}{l}\text { Daily Excretion in Gastrointestina } \\
\text { Tract }\end{array}$} \\
\hline & & & & RIHSA (\%) & Albumin $^{1}(\mathrm{~g})$. \\
\hline $\begin{array}{r}9 \\
14 \\
15 \\
16\end{array}$ & $\begin{array}{l}\text { Crohn's disease (in remission) } \\
\text { Gluten enteropathy } \\
\text { Idiopathic steatorrhoea } \\
\text { Crohn's disease (in remission) }\end{array}$ & $\begin{array}{l}3 \cdot 8 \\
5 \cdot 0 \\
5 \cdot 5 \\
3 \cdot 5\end{array}$ & $\begin{array}{r}18 \cdot 2 \\
7 \cdot 7 \\
12 \cdot 6 \\
20 \cdot 5\end{array}$ & $\begin{array}{l}2 \cdot 4 \\
2 \cdot 5 \\
2 \cdot 4 \\
2 \cdot 4\end{array}$ & $\begin{array}{l}5 \cdot 1 \\
4 \cdot 7 \\
5 \cdot 4 \\
5 \cdot 2\end{array}$ \\
\hline
\end{tabular}

'Calculated from the TEA.

TABLE $X$

EFFECT OF TREATMENT IN STEATORRHOEA ON THE EXCRETION OF RIHSA INTO THE GUT

\begin{tabular}{|c|c|c|c|c|c|c|}
\hline \multirow{2}{*}{ Case No. } & \multicolumn{3}{|c|}{ Disease Active } & \multicolumn{3}{|c|}{ In Remission } \\
\hline & $\begin{array}{l}T_{\frac{1}{2}} \\
(\text { days })\end{array}$ & $\begin{array}{l}\text { Albumin Pool } \\
\text { (g.) }\end{array}$ & $\begin{array}{l}\text { RIHSA Excretion } \\
\text { (\% of dose) }\end{array}$ & $\begin{array}{l}T_{\frac{1}{2}} \\
\text { (days) }\end{array}$ & $\begin{array}{l}\text { Albumin Pool } \\
(\mathrm{g} .)\end{array}$ & $\begin{array}{l}\text { RIHSA Excretion } \\
\text { (\% of dose) }\end{array}$ \\
\hline $\begin{array}{l}14 \\
15\end{array}$ & $\begin{array}{l}5.1 \\
9.0\end{array}$ & $\begin{array}{l}180 \\
100\end{array}$ & $\begin{array}{l}17.2 \\
10.7\end{array}$ & $\begin{array}{r}5.5 \\
10 \cdot 1\end{array}$ & $\begin{array}{l}292 \\
190\end{array}$ & $\begin{array}{l}2.4 \\
2.5\end{array}$ \\
\hline
\end{tabular}

survival of RIHSA in the plasma, with subsequent excretion of the ${ }^{131}$ I so liberated.

ALBUMIN TURNOVER STUDIES These studies indicated that there was no relation between the $T_{t}$ and the presence of hypoproteinaemia and oedema in patients with small bowel disease. The $T_{1}$ in patients without oedema was slightly greater than in four with oedema due to hypoproteinaemia.

There seem to be at least two possible explanations for this discrepancy:-

1 There are two types of persons: those who have a reserve of regenerative capacity for the manufacture of plasma proteins to meet the needs of increased destruction, and those in whom this reserve is lacking. We have no evidence for this explanation.

2 In cases of hypoproteinaemia where protein is being lost through the gastrointestinal tract there may be an inability adequately to reabsorb and use the products of digestion in the presence of enteropathy. The plasma albumin seems to be in equilibrium at a lower level. At this level the absolute amounts turned over will be lower than at normal levels. For example, the albumin pool in Case 9 (when active) was $98 \mathrm{~g}$. and her daily turnover was $20.6 \%$. Hence albumin turned over in a day

$$
=\frac{20 \cdot 6}{100} \times 98=20 \cdot 2 \mathrm{~g} \text {. }
$$

If her pool was $300 \mathrm{~g}$. the daily turnover would be

$$
\frac{20 \cdot 6}{100} \times 300=61 \cdot 8 \mathrm{~g} .
$$

Thus if she was unable to re-use the proteins excreted she would have to 'set' her albumin at a lower level.
STUDY OF FAECAL RADIOACTIVITY USING RIHSA From the study of control subjects and of patients with functionally normal gastrointestinal tracts, it was seen that about $1.8 \%$ of the albumin was excreted daily and a similar amount was broken down endogenously. This indicates that albumin is normally lost from the albumin pool in two ways: half by endogenous breakdown and half in the gastrointestinal tract.

This dual mechanism was found in most of the patients. However, in contradistinction to the control subjects, endogenous breakdown of RIHSA in most of the patients was greater than intestinal loss. This was particularly obvious in the patients with disease of the small bowel but without hypoproteinaemia or oedema (Table IX).

COMPARISON OF ${ }^{131}$ I-PVP AND RIHSA In patients with hypoproteinaemia and oedema there was a marked increase in the excretion of RIHSA whereas the PVP excretion was normal and did not reveal the true state of affairs in these patients. This lack of correlation is shown in Table XI.

The fact that the excretion of RIHSA may sometimes be as high as $4.8 \%$ per day without a fall in plasma albumin (Table VII) suggests that RIHSA excretion must be above about $5 \%$ per day before hypoproteinaemia will appear.

EFFECT OF THERAPY There was a marked decrease in RIHSA excretion in two patients with steatorrhoea after treatment with a gluten-free diet (Case 14) and with antibiotics (Case 15). In both the excretion was 
TABLE XI

CORRELATION OF RIHSA EXCRETION AND ${ }^{131}$ I-PVP EXCRETION

\begin{tabular}{|c|c|c|c|c|}
\hline Case No. & Condition & $\begin{array}{l}T \frac{1}{2} \\
\text { (days) }\end{array}$ & $\begin{array}{l}\text { Excretion of } \\
\text { RIHSA into } \\
\text { Gastrointestinal } \\
\text { Tract } \\
(\% \text { of dose })\end{array}$ & $\begin{array}{l}{ }^{131} I-P V P \text { Excretion } \\
(\% \text { of dose })\end{array}$ \\
\hline 15 & Idiopathic steatorrhoea (active) & $5 \cdot 1$ & $17 \cdot 2$ & $1 \cdot 1$ \\
\hline 15 & Idiopathic steatorrhoea (partially treated) & $5 \cdot 5$ & 2.4 & 0.87 \\
\hline 9 & Crohn's disease (active) & $3 \cdot 5$ & 18.9 & 0.98 \\
\hline 10 & Crohn's disease (active) & $2 \cdot 8$ & 15.5 & $\mathbf{0} 38$ \\
\hline 17 & Tuberculous strictures of small intestine & $3 \cdot 2$ & 12.9 & $1 \cdot 3$ \\
\hline
\end{tabular}

reduced to within the range found in non-specific bowel conditions such as obstruction.

Patients with active idiopathic steatorrhoea lose considerable amounts of RIHSA in the faeces (Cases 14 and 15). The use of RIHSA and Amberlite described here may be a fruitful method for studying the effect of various modes of treatment on such small bowel disorders.

\section{SUMMARY}

Methods of studying gastrointestinal protein loss are reviewed. The advantages of RIHSA and the disadvantages of ${ }^{131}$ I-PVP are discussed.

Three control subjects and 15 patients with different intestinal disorders were studied (a) using intravenous RIHSA to estimate the albumin turnover, $(b)$ measuring faecal radioactivity after intravenous injection of ${ }^{131} \mathrm{I}-\mathrm{PVP}$, and $(c)$ measuring the faecal excretion of RIHSA using oral Amberlite resin IRA-400 (Cl.).

Jejunal intubation demonstrated that intact RIHSA was excreted into the jejunal lumen. The Amberlite resin was found to be capable of absorbing about $80 \%$ of RIHSA in the gut.

Albumin turnover studies indicated that there was no relation between the $T_{\frac{1}{2}}$ and the presence of hypoproteinaemia and oedema. The possible reasons for this are discussed.

The faecal excretion of ${ }^{131}$ I-PVP was normal in our patients with hypoproteinaemia.

Studies of the excretion of injected RIHSA indicated that the turnover of albumin in control subjects was dependent half on endogenous albumin breakdown, and half on excretion and digestion of body albumin in the intestine. The actual amount of RIHSA excreted into the gastrointestinal tract per day was less than $2 \%$ of the injected dose.

Patients with inactive or non-specific bowel conditions excreted up to about $4 \%$ of the injected dose of RIHSA. This figure increased to about $9 \%$ in patients with active small bowel disease associated with hypoproteinaemia and oedema. Patients with small bowel disease but no hypoproteinaemia or oedema excreted, with one exception, under $4 \%$ of the injected dose of RIHSA daily.

In two patients with steatorrhoea the daily RIHSA excretion after treatment fell from 10.7 and $17.2 \%$ respectively to about $2.5 \%$ and the albumin pools increased by about 60 to $100 \%$ although the $T_{\frac{1}{2}}$ remained abnormally short in both.

We are grateful to Dr. R. S. Gordon, National Heart Institute, Bethesda, Maryland, U.S.A., for supplying the ${ }^{131}$ I-PVP used, and to Dr. J. R. Mallard, Hammersmith Hospital, for helping us to obtain it.

We are particularly indebted to Dr. M. Lubran for help with many aspects of this work.

\section{REFERENCES}

Berson, S. A., Yalow, R. S., Schreiber, S. S., and Post, J. (1953). Tracer experiments with $\mathrm{I}^{131}$-labelled human serum albumin: distribution and degradation studies. J. clin. Invest., 32 746-768.

Gordon, R. S. (1959). Exudative enteropathy. Abnormal permeability of the gastrointestinal tract demonstrable with labelled polyvinylpyrrolidone. Lancet, 1, 325-326.

Gross, P. A. M., Embree, L. J., Bally, P., Shipp, J. C., and Thorn, G. W. (1960). Hypoalbuminemia (with anasarca) due to hypercatabolism, serum protein exudation into the gastrointestinal tract, increased capillary permeability and hypoanabolism. Amer. J. Med., 29, 386-404.

Holman, H., Nickel, W. F. Jr., and Sleisenger, M. H. (1959). Hypoproteinemia antedating intestinal lesions, and possibly due to excessive serum protein loss into the intestine. Ibid, 27, 963975.

McFarlane, A. S. (1956). Labelling of plasma proteins with radioactive iodine. Biochem. J., 62, 135.

Parkins, R. A., Dimitriadou, A., and Booth, C. C. (1960). The rates and sites of absorption of ${ }^{131}$ I-labelled albumin and sodium ${ }_{131}$ in the rat. Clin. Sci., 19, 595-604.

Schwartz, M., and Jarnum, S. (1959). Gastrointestinal protein loss in idiopathic (hypercatabolic) hypoproteinaemia. Lancet, 1, 327-330.

proteinaemia. Cases examined by ${ }^{131}$ I-labelled albumin. Brit. med. J., 1, 14-17. 